\title{
FIRST RECORD OF AN INDO-PACIFIC GAPER, CHAMPSODON VORAX (ACTINOPTERYGII: PERCIFORMES: CHAMPSODONTIDAE), FROM THE AEGEAN SEA, TURKEY
}

\author{
İlker AYDIN and Okan AKYOL* \\ Ege University Faculty of Fisheries, Urla, Izmir, Turkey
}

\begin{abstract}
Aydın I., Akyol O. 2015. First record of an Indo-Pacific gaper, Champsodon vorax (Actinopterygii: Perciformes: Champsodontidae), from the Aegean Sea, Turkey. Acta Ichthyol. Piscat. 45 (2): 207-209.

Abstract. A specimen of Champsodon vorax Günther, 1867, of $113 \mathrm{~mm}$ SL, was caught on 6 September 2014 with a bottom trawl from the entrance of the Bay of Izmir, north-eastern Aegean Sea at a depth of $65 \mathrm{~m}$. The presently reported study constitutes the first record for the Aegean Sea but also the fourth record for the Mediterranean Sea. The specimen described in this paper is the largest individual reported to date from the Mediterranean. As it is evident from the spatial dynamics of all successive records of $C$. vorax in the Mediterranean this gaper seems to be a rapidly expanding species. It disperses both westwards and northwards.
\end{abstract}

Keywords: crocodile toothfish, alien fish, Izmir Bay, measurement, dispersion

The family Champsodontidae known as gapers, or crocodile toothfishes, comprises only a single genus, Champsodon Günther, 1867, with thirteen species (Nelson 2006). The characteristics of the family are elongate cylindrical body with small rough scales, large mouth with long slender teeth; two dorsal fins, feeble spines and they are small carnivorous fish of fairly deep water of the Indo-Pacific Ocean (Smith 1965).

Champsodon vorax Günther, 1867 is known from the Indo-West Pacific, the Maldives, Australia, Vietnam, the Philippines, Indonesia, and Guam (Froese and Pauly 2014). In the Mediterranean Sea, it has been recorded for the first time in May 2010 (2 specimens) and November 2010 ( 2 specimens) in the coastal waters of Beirut (Bariche 2010, 2011). Two years later, another record of $C$. vorax was made from the Gulf of Antalya, Turkey (Gökoğlu and Özvarol 2013). Recently, another two champsodontid species Champsodon capensis Regan, 1908 (see Dalyan et al. 2012, Gökoğlu and Özvarol 2013) and Champsodon nudivittis (Ogilby, 1895) (see Çiçek and Bilecenoglu 2009, Goren et al. 2011, Gökoğlu et al. 2011, Kalogirou and Corsini-Foka 2012, Filiz et al. 2014) were also reported from the Eastern Mediterranean coasts.

On 6 September 2014, a specimen of Champsodon vorax (Fig. 1), measuring $113 \mathrm{~mm}$ standard length (SL), was captured by a commercial bottom trawl (44 $\mathrm{mm}$ stretched mesh size) from the entrance of Izmir Bay $\left(38^{\circ} 41^{\prime} \mathrm{N}, 26^{\circ} 36^{\prime} \mathrm{E}\right)$ (Fig. 2) at a depth of $65 \mathrm{~m}$. The specimen was fixed in $5 \%$ formaldehyde solution and stored in the fish collection of the Ege University, Fisheries Faculty (ESFM-PIS/2014-010). Diagnostic features of the specimen were examined under a light microscope and all measurements were done with a digital calliper.

Champsodon vorax differs from its congeners by a fully scaled thoracic ventral part, patches of scales on chin, belly scaled to midway between anus and origin of pelvic fins; a patch of scales behind origin of pelvic fins. Goren et al. (2014) provided diagrams and pictures of ventral view of $C$. vorax and our sample was consistent with it. Diagnostic characteristics were as follows: first dorsal fin rays $\mathrm{V}$, second dorsal fin rays 20 , anal fin rays 18 , pectoral fin rays 12 , ventral fin rays $5-5$. The sampled specimen has scales in thoracic ventral part (Fig. 1A), scales in front of the anus (Fig. 1B), and scales in chin (Fig. 1C), and has eleven gill rakers on the first gill arch. There were no melanophores along the pectoral fin rays. Selected body proportions (in relation to standard length): head length (HL) $26.5 \%$, pre-dorsal length $32.7 \%$, pre-anal length $51.3 \%$, pre-pectoral length $28.3 \%$, and maximum body depth $17.3 \%$. Proportions in relation to HL: eye diameter $20.3 \%$ and pre-orbital length $30.7 \%$. All measurements, counts, and colour patterns determined were in accordance with descriptions of Bariche (2010), Gökoğlu and Özvarol (2013), Goren et al. (2014), and Froese and Pauly (2014). It should also be emphasized that the specimen described in the presently reported study is the largest individual reported to date from the Mediterranean. 


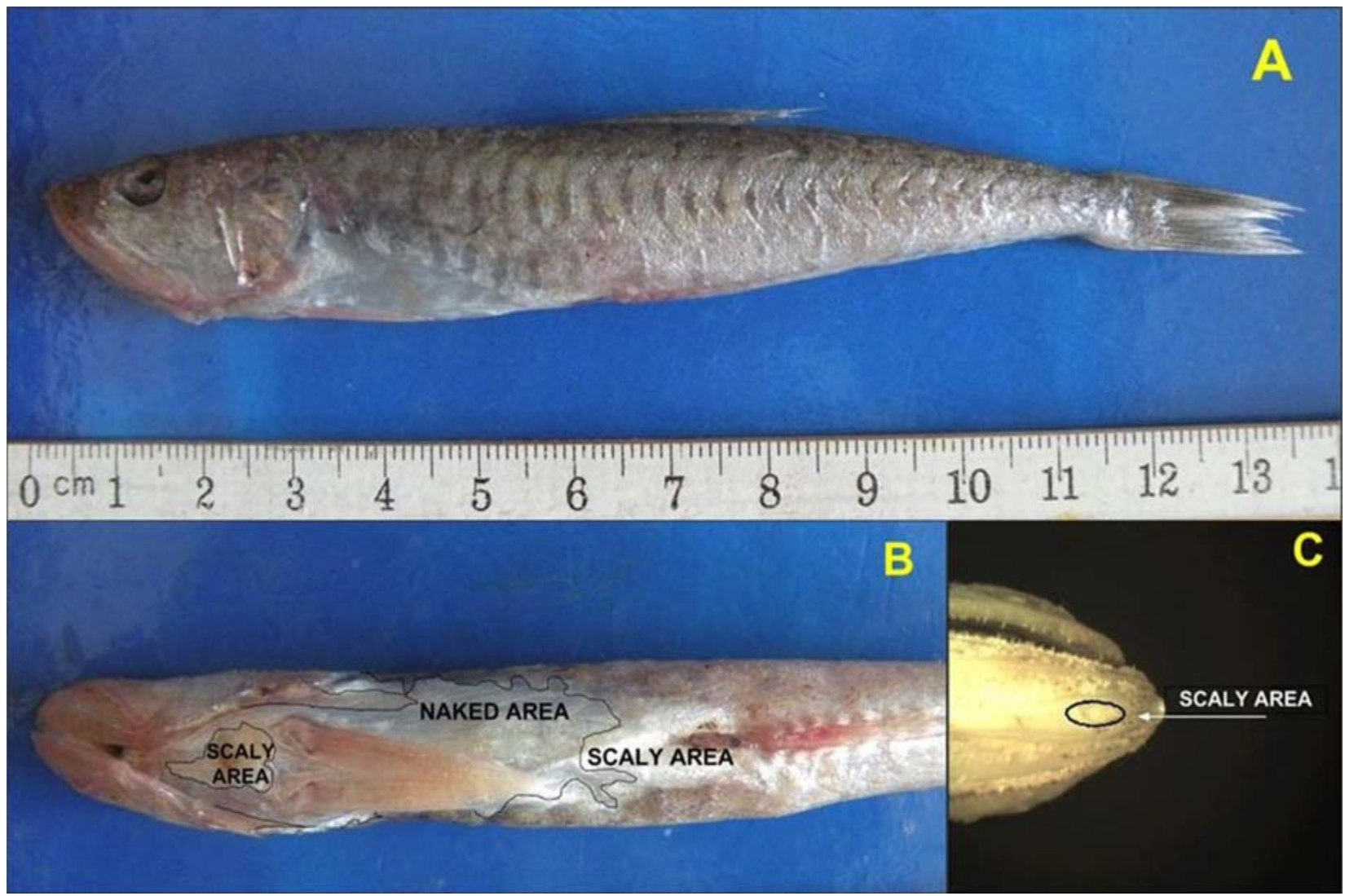

Fig. 1. Champsodon vorax, caught in the Aegean Sea, Izmir Bay, $113 \mathrm{~mm}$ SL: general view (A), scale patterns on ventral thoracic-, abdominal-, and anal regions $(\mathbf{B})$, chin $(\mathbf{C})$

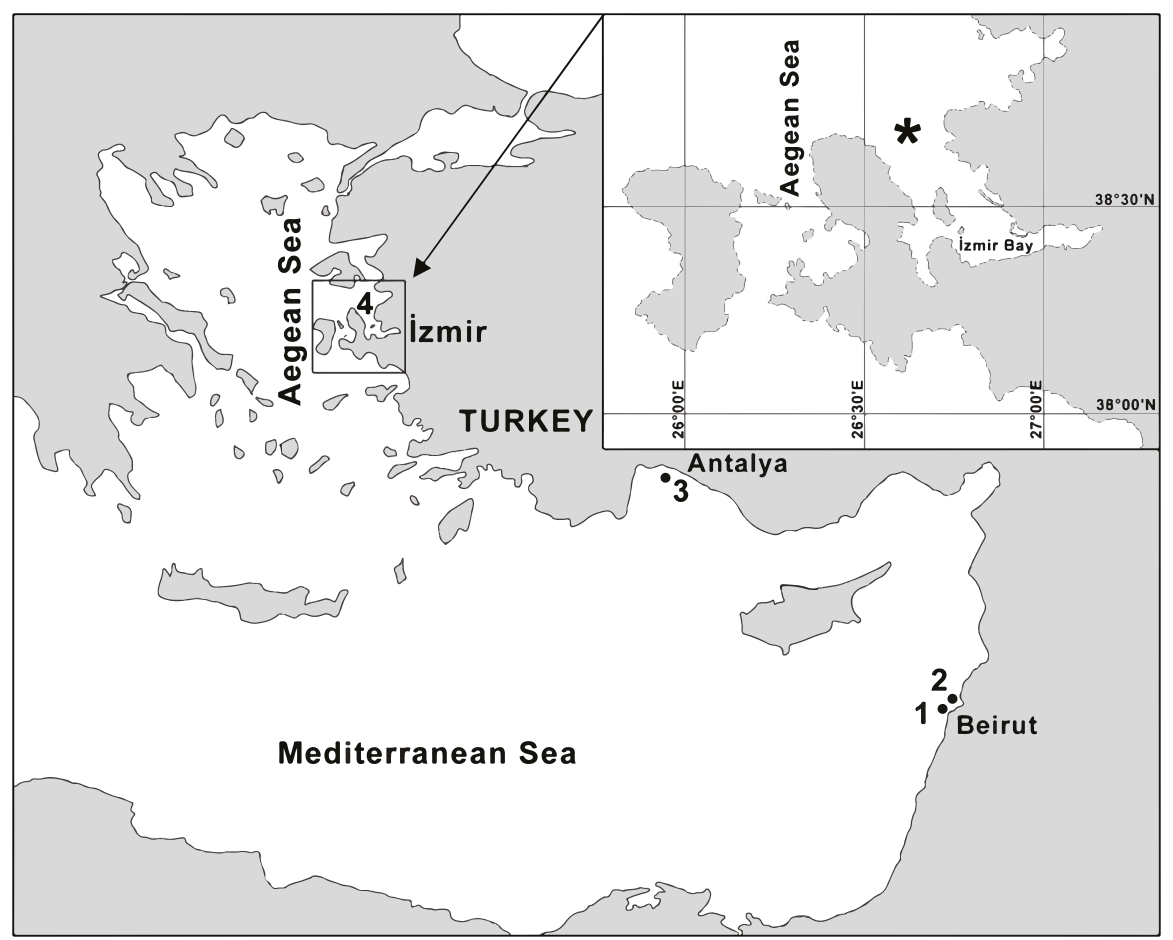

Fig. 2. Westward range extension of Champsodon vorax the coastal areas of the Mediterranean Sea (black dots and star indicate consecutive reports and the most recent record, respectively): $1=13$ and 30 May 2010 (Bariche 2010); 2 $=10$ November 2010 (Bariche 2011); 3 = 25 September 2012 (Gökoğlu and Özvarol 2013); 4 = 6 September 2014 (this study) 
Table 1

Records of Champsodon vorax in the Mediterranean Sea

\begin{tabular}{lcccccc}
\hline \multicolumn{1}{c}{ Location } & Coordinates & $\begin{array}{c}\text { Depth } \\
{[\mathrm{m}]}\end{array}$ & Date & $n$ & $\begin{array}{c}\text { SL } \\
{[\mathrm{mm}]}\end{array}$ & $\begin{array}{c}\text { Reference } \\
\text { Batroun, Lebanon }\end{array}$ \\
\hline Jounich Bay, Lebanon & $34^{\circ} 15^{\prime} \mathrm{N}, 35^{\circ} 39^{\prime} \mathrm{E}$ & 150 & 13 May 2010 & 1 & 67.4 & Bariche 2010 \\
Beirut, Lebanon & $33^{\circ} 59^{\prime} \mathrm{N}, 35^{\circ} 36^{\prime} \mathrm{E}$ & 30 & 30 May 2010 & 1 & 93.0 & Bariche 2010 \\
Antalya, Turkey & $33^{\circ} 55^{\prime} \mathrm{N}, 35^{\circ} 32^{\prime} \mathrm{E}$ & 45 & 10 Nov 2010 & 2 & $93.7-81.6$ & Bariche 2011 \\
Izmir Bay, Turkey & $36^{\circ} 49^{\prime} \mathrm{N}, 30^{\circ} 50^{\prime} \mathrm{E}$ & $30-100$ & 25 Sep 2012 & 7 & $105-110$ & Gökoğlu and Özvarol 2013 \\
\hline
\end{tabular}

$n=$ number of fish collected, $\mathrm{SL}=$ standard length.

The first occurrence of the Champsodon vorax in the Mediterranean Sea has been reported by Bariche (2010) and since then, three consecutive records have been provided within the period more than 3 years (Table 1). As it is evident from the spatial dynamics of all successive records of C. vorax in the Mediterranean (Table 1, Fig. 2), this gaper seems to be a rapidly expanding species. The presently reported record shows that $C$. vorax disperses rapidly both westwards and northwards, reaching the Aegean Sea. There is no certainty on the mode of introduction of $C$. vorax since it has not yet been reported from the Red Sea (Bariche 2010, Goren et al. 2014). A probable mode of introduction could be a transport with ship ballast waters. Yet, the occurrences of a total of 12 specimens of C. vorax in three different localities at different depths and of different sizes indicate a successful establishment of a self-maintaining population in the Levantine basin. This hypothesis, however, needs further investigation.

\section{REFERENCES}

Bariche M. 2010. Champsodon vorax (Teleostei: Champsodontidae), a new alien fish in the Mediterranean. Aqua 16 (4): 197-200.

Bariche M. 2011. First record of the cube boxfish Ostracion cubicus (Ostraciidae) and additional records of Champsodon vorax (Champsodontidae) from the Mediterranean. Aqua 17 (4): 181-184.

Çiçek E., Bilecenoglu M. 2009. A new alien fish in the Mediterranean Sea: Champsodon nudivittis (Actinopterygii: Perciformes: Champsodontidae). Acta Ichthyologica Piscatoria 39 (1): 67-69.

DOI: 10.3750/AIP2009.39.1.14

Dalyan C., Yemişken E., Eryılmaz L. 2012. A new record of gaper (Champsodon capensis Regan, 1908) in the Mediterranean Sea. Journal Applied Ichthyology 28 (5): 834-835.

DOI: $10.1111 / \mathrm{j} .1439-0426.2012 .02019 . \mathrm{x}$

Filiz H., Akcinar S.C., Irmak E. 2014. Occurrence, length-weight and length-length relationships of Champsodon nudivittis (Ogilby, 1895) in the Aegean Sea. Journal Applied Ichthyology 30 (2): 415-417. DOI: $10.1111 /$ jai.12216
Froese R., Pauly D. (eds.) 2014. FishBase. [version 08/2014] http://www.fishbase.org

Goren M., Stern N., Galil B.S., Diamant A. 2011. On the occurrence of the Indo-Pacific Champsodon nudivittis (Ogilby, 1895) (Perciformes, Champsodontidae) from the Mediterranean coast of Israel, and presence of the species in the Red Sea. Aquatic Invasions 6 (Suppl. 1): S115-S117. DOI: 10.3391/ai.2011.6.S1.026

Goren M., Ganga U., Jinesh T.P. 2014. Champsodon vorax and Champsodon nudivittis, two new records from the north-eastern Arabian Sea (Perciformes, Champsodontidae). Marine Biodiversity Records 7: e45. DOI: $10.1017 / \mathrm{S} 1755267214000505$

Gökoğlu M., Ünlüsayın M., Balcı B.A., Özvarol Y., Çolak H. 2011. Two alien fish in the Gulf of Antalya: Apogon queketti Gilchrist, 1903 (Apogonidae) and Champsodon nudivittis (Ogilby, 1895) (Champsodontidae). Zoology in the Middle East 54 (1): 138-140. DOI: $10.1080 / 09397140.2011 .10648888$

Gökoğlu M., Özvarol Y. 2013. Additional records of Champsodon vorax and Champsoson capensis (Actinopterygii: Perciformes: Champsodontidae) from the eastern Mediterranean Sea. Acta Ichthyologica et Piscatoria 43 (1): 79-82. DOI: $10.3750 / A I P 2013.43 .1 .12$

Kalogirou S., Corsini-Foka M. 2012. First record of the Indo-Pacific Champsodon nudivittis (Ogilby, 1895) (Perciformes, Champsodontidae) in the Aegean waters (eastern Mediterranean Sea). BioInvasions Records 1 (3): 229-233.

DOI: $10.3391 /$ bir.2012.1.3.10

Nelson J.S. 2006. Fishes of the world. 4th edn. John Wiley and Sons, New York NY, USA.

Smith J.L.B. 1965. The sea fishes of Southern Africa. 5th Edition, Central News Agency, Cape Town, Republic of South Africa.

Received: 24 September 2014 Accepted: 3 February 2015 Published electronically: 30 June 2015 